\title{
Haloincola saccharolytica subsp. senegalensis subsp. nov., Isolated from the Sediments of a Hypersaline Lake, and Emended Description of Haloincola saccharolytica
}

\author{
J.-L. CAYOL ${ }^{1}$ B. OLLIVIER, ${ }^{1 *}$ A. LAWSON ANANI SOH,${ }^{1}$ M.-L. FARDEAU, ${ }^{1,2}$ E. AGERON, ${ }^{3}$ \\ P. A. D. GRIMONT, ${ }^{3}$ G. PRENSIER, ${ }^{4}$ J. GUEZENNEC,${ }^{5}$ M. MAGOT, ${ }^{6}$ AND J.-L. GARCIA ${ }^{1}$ \\ Laboratoire de microbiologie ORSTOM, Université de Provence, 13331 Marseille Cedex $3,{ }^{1}$ Laboratoire de chimie \\ bactérienne, Centre National de la Recherche Scientifique, 13277 Marseille Cedex 9, ${ }^{2}$ Unité des Entérobactéries, \\ INSERM U199, Institut Pasteur, 75724 Paris Cedex $15,{ }^{3}$ Laboratoire de microbiologie, Université Blaise Pascal, \\ 63177 Aubière Cedex, ${ }^{4}$ Laboratoire de chimie et de corrosion marine, IFREMER, 29273 Brest Cedex, ${ }^{5}$ \\ and Unité de microbiologie industrielle, SANOFI Recherche, 31328 Labège Cedex, ${ }^{6}$ France
}

\begin{abstract}
A new halophilic chemoorganotrophic bacterium (strain $\mathrm{H150}^{\mathrm{T}}[\mathrm{T}=$ type strain $]$ ) related to Haloincola saccharolytica was isolated from the hypersaline sediments of Retba Lake in Senegal. This organism was a rod-shaped, motile, non-spore-forming, gram-negative obligate anaerobe that grew optimally in the presence of $10 \% \mathrm{NaCl}$ and at $40^{\circ} \mathrm{C}$. The DNA base composition was $31.7 \pm 0.3 \mathrm{~mol} \%$ guanine plus cytosine. The fermentation products from glucose were acetate, $\mathrm{H}_{2}$, and $\mathrm{CO}_{2}$. The fermentable substrates included cellobiose, fructose, glucose, maltose, lactose, glycerol, mannitol, mannose, ribose, raffinose, and sucrose. Penicillin G, cephalosporin $\mathrm{C}$, novobiocin, vancomycin, and chloramphenicol inhibited growth. As determined by DNA-DNA hybridization, strain $\mathrm{H150}^{\mathrm{T}}$ was $71 \%$ related to $\mathrm{H}$. saccharolytica, with $\Delta T_{m}$ value of $6.0^{\circ} \mathrm{C}$. However, strain $\mathrm{H150}^{\mathrm{T}}$ exhibited marked phenotypic differences, particularly in the range of substrates used, when it was compared with the type species of the genus Haloincola. For this isolate we propose the name Haloincola saccharolytica subsp. senegalensis subsp. nov.; strain H150 (= DSM 7379) is the type strain of this taxon.
\end{abstract}

Although most studies of hypersaline environments have been limited to aerobic organisms, these ecosystems are also inhabited by a wide range of anaerobic microorganisms, including photosynthetic, methanogenic, fermentative, and sulfate-reducing bacteria (14). In the past few years, there has been an increased interest in searching for new strains of anaerobic bacteria in these environments in order to understand the mechanisms involved in osmotic regulation and enzymatic activities at high salt concentrations.

Only the following 11 fermentative, strictly anaerobic, moderately halophilic bacteria have been described to date (12): Haloanaerobium praevalens, from bottom sediments of the Great Salt Lake in Utah (24); Halobacteroides halobius (17), Sporohalobacter lortetii, and Sporohalobacter marismortui (16), from sediments of the Dead Sea; Halobacteroides acetoethyli$c u s$, from deep subsurface gas-bearing sandstones and brine waters associated with an injection water filter on an offshore oil rig in the Gulf of Mexico (19); Haloanaerobacter chitinovorans, from a solar saltern in southern California (10); Halobacteroides lacunaris, from hypersaline Lake Chokrak (Kerch Peninsula) (25); Haloincola saccharolytica (27), Acetohalobium arabaticum (26), and Halocella cellulolytica (21), from Lake Sivash; and Halothermothrix orenii, from sediment from a Tunisian hypersaline lake (chott El-Guettar) (4).

A 16S rRNA oligonucleotide cataloging analysis of most of these species showed that they are related to each other and are different in some ways from members of other subgroups belonging to the eubacterial kingdom. A new family, the Haloanaerobiaceae, has been described by Oren et al. (15).

All bacteria belonging to the family Haloanaerobiaceae produce acetate from carbohydrates. The homoacetogenesis

\footnotetext{
* Corresponding author. Mailing address: Laboratoire de microbiologie, ORSTOM, Case 87, Université de Provence, 3 Pl. Victor Hugo, 13331 Marseille Cedex 03, France.
}

process occurs only in $A$. arabaticum (26) and Haloincola saccharolytica (27), but Haloincola saccharolytica is able to oxidize carbohydrates, while $A$. arabaticum is not. Halobacteroides lacunaris, Halobacteroides acetoethylicus, and Halobacteroides halobius produce ethanol in addition to acetate, while $S$. lortetii, S. marismortui, and Haloanaerobium praevalens produce diverse volatile fatty acids. The metabolic products obtained from cellulose oxidation by Halocella cellulolytica include ethanol, acetate, and lactate (21).

In this paper we describe the isolation from the sediments of a hypersaline lake of a moderately halophilic chemoorganotrophic bacterium (strain $\mathrm{H} 150^{\mathrm{T}}$ [ $\mathrm{T}=$ type strain]). Acetate is the only fatty acid produced by this organism during glucose fermentation. The results of DNA relatedness, physiological, and metabolic studies justified assignment of this strain to a new subspecies of the genus Haloincola.

\section{MATERIALS AND METHODS}

Strain origin. Strain $\mathrm{H} 150^{\mathrm{T}}$ was isolated from the sediment of hypersaline Retba Lake near Dakar (Senegal); this lake is located $100 \mathrm{~m}$ from the Atlantic Ocean. Sediment samples were obtained in July 1988 at a depth of $1.50 \mathrm{~m}$. The in situ temperature of the sediment was about $32^{\circ} \mathrm{C}$, and the total salt concentration in the water was $340 \mathrm{~g} \mathrm{liter}^{-1}$. The $\mathrm{pH}$ was 7.15 .

The following five type strains of haloanaerobic bacteria were used for DNA relatedness studies: Haloincola saccharolytica Z-7787 (= DSM 6645), S. lortetii MD-2 (= ATCC 35059), $S$. marismortui DY-1 (= ATCC 35420), Halobacteroides acetoethylicus EIGI ( = DSM 3532), and Haloanaerobium praevalens GSL (= DSM 2228).

Culture medium. Strain $\mathrm{H} 150^{\mathrm{T}}$ was isolated on medium containing (per liter) $1.0 \mathrm{~g}$ of $\mathrm{NH}_{4} \mathrm{Cl}, 0.3 \mathrm{~g}$ of $\mathrm{KH}_{2} \mathrm{PO}_{4}, 20.0 \mathrm{~g}$ of $\mathrm{MgCl}_{2} \cdot 6 \mathrm{H}_{2} \mathrm{O}, 2.0 \mathrm{~g}$ of $\mathrm{CaCl}_{2} \cdot 2 \mathrm{H}_{2} \mathrm{O}, 4.0 \mathrm{~g}$ of KCl, $1.0 \mathrm{~g}$ of $\mathrm{CH}_{3} \mathrm{COONa} \cdot 3 \mathrm{H}_{2} \mathrm{O}, 10.0 \mathrm{~g}$ of glucose, $150 \mathrm{~g}$ of $\mathrm{NaCl}, 3.0 \mathrm{~g}$ of bio-Trypticase (bioMérieux), $3.0 \mathrm{~g}$ of yeast extract (Difco), 1 
$\mathrm{ml}$ of a $0.1 \%(\mathrm{wt} / \mathrm{vol})$ resazurin solution, $1 \mathrm{ml}$ of a trace element solution (9), and $50 \mathrm{ml}$ of the mineral solution of Balch et al. (1).

The medium was adjusted to $\mathrm{pH} 7$ with $10 \mathrm{M} \mathrm{KOH}$, boiled under a stream of $\mathrm{O}_{2}$-free $\mathrm{N}_{2}$, and cooled to room temperature. Portions $(20 \mathrm{ml})$ of medium were distributed into $60-\mathrm{ml}$ serum bottles that were stoppered with butyl rubber stoppers according to the Hungate anaerobic technique (8). The serum bottles were outgassed with $\mathrm{N}_{2}-\mathrm{CO}_{2}(80: 20)$ and sterilized for $45 \mathrm{~min}$ at $110^{\circ} \mathrm{C}$. After autoclaving, $0.2 \mathrm{ml}$ of $2 \% \mathrm{Na}_{2} \mathrm{~S} \cdot 9 \mathrm{H}_{2} \mathrm{O}$ and $1 \mathrm{ml}$ of $10 \% \mathrm{NaHCO}_{3}$ (both sterile, anaerobic solutions), as well as $0.1 \mathrm{ml}$ of a filter-sterilized $0.2 \%$ sodium dithionite solution, were injected into each bottle. The final $\mathrm{pH}$ was 7.0. Roll tubes were prepared by adding $2 \%$ agar (Difco) to the medium. In some experiments, $5-\mathrm{ml}$ portions of medium were distributed into Hungate tubes as described above. To avoid precipitation in the medium, lower concentrations of $\mathrm{MgCl}_{2} \cdot 6 \mathrm{H}_{2} \mathrm{O}\left(2.0 \mathrm{~g} \mathrm{liter}^{-1}\right)$ and $\mathrm{CaCl}_{2} \cdot 2 \mathrm{H}_{2} \mathrm{O}\left(0.2 \mathrm{~g} \mathrm{liter}^{-1}\right)$ were used.

Isolation procedure. Samples of the sediment were used to prepare enrichment cultures for halophilic sulfate reducers (13) at four $\mathrm{NaCl}$ concentrations $\left(50,100,150,200 \mathrm{~g} \mathrm{liter}^{-1}\right)$. Another set of cultures was prepared to isolate glucoseoxidizing microorganisms from the enrichment cultures at the same concentrations of $\mathrm{NaCl}$. After several transfers, the enrichment cultures were diluted in roll tube media. Two or three colonies from each enrichment culture were picked and rediluted in an agar dilutions series. This process was repeated in order to purify the cultures.

Purity was checked by microscopic examination after growth on a complex, rich medium with or without $\mathrm{NaCl}$.

Analytical techniques. The presence of volatile fatty acids and alcohols was detected with a Delsi series 30 chromatograph by using an SP-1000 column $\left(1 \% \mathrm{H}_{3} \mathrm{PO}_{4}\right.$ on Chromosorb WAW) operated at $150^{\circ} \mathrm{C}$; nitrogen was used as the carrier gas. A flame ionization detector and a Delsi integrator were used. The amount of hydrogen was determined with a Girdel series 30 gas chromatograph equipped with a thermal conductivity detector. The column was filled with Carbosphere SS (60/80 mesh).

Glucose, lactate, and formate were assayed with diluted samples by high-performance liquid chromatography (HPLC), using an Analprep 93 pump (Touzart et Matignon, Vitry sur Seine, France) and an ORH 801 column (Interaction Chemicals, Mountain View, Calif.); the flow rate was $0.6 \mathrm{ml} \mathrm{min}{ }^{-1}$, the volume of the injection loop was $20 \mu \mathrm{l}$, the column temperature was $35^{\circ} \mathrm{C}$, and the detector was a differential refractometer (Knauer, Berlin, Germany). Bacterial growth was quantified with a Shimadzu model UV 160A spectrophotometer by measuring the increase in turbidity at $660 \mathrm{~nm}$ in anaerobic Hungate tubes. All experiments were duplicated.

Lipid analysis. Lipid extraction, fatty acid purification, and quantification by capillary gas chromatography were performed as described previously $(13,23)$. The methanol-water residue of a Bligh-Dyer extraction preparation was dried under a vacuum and then rediluted with $1 \mathrm{~N} \mathrm{HCl}$. After the supernatant was refluxed at $100^{\circ} \mathrm{C}$ for $5 \mathrm{~h}$ and cooled, it was transferred to a separatory funnel. The lipids were extracted with several washes of chloroform. The chloroform phase was allowed to dry under a vacuum, and the samples were esterified with a methanol-dichloromethane- $\mathrm{HCl}$ mixture for $1 \mathrm{~h}$ at $100^{\circ} \mathrm{C}$. After addition of dichloromethane and water and thorough mixing, the dichloromethane layer was recovered, evaporated in a stream of nitrogen, and spotted onto a thin-layer chromatography plate. After ascending chromatography in a solvent consisting of hexane and diethyl ether $(1: 1$, $\mathrm{vol} / \mathrm{vol}$ ), the hydroxy fatty acid bands were scrapped from the plate and eluted from the silica gel with chloroform-methanol $(1: 1, \mathrm{vol} / \mathrm{vol})$ into screw-cap glass test tubes.

The hydroxy esters were then converted to their corresponding trimethylsilyl esters by using $\mathrm{N}, \mathrm{O}$-bis(trimethylsilyl)trifluoroacetamide, dissolved in hexane, and analyzed by gas chromatography and gas chromatography-mass spectrometry.

The fatty acid nomenclature used has been described previously (13). The prefix $\mathrm{OH}$ indicates that there is a hydroxyl group at the position indicated from the carboxyl end.

Electron microscopy. Cells were negatively stained with $4 \%$ (wt/vol) uranyl acetate in distilled water. Cells from an exponentially growing culture were fixed for $1 \mathrm{~h}$ in $0.07 \mathrm{M}$ sodium cacodylate buffer ( $\mathrm{pH} 7.3$ ) containing $1.2 \%$ glutaraldehyde and $0.05 \%$ ruthenium red.

After the samples were washed in cacodylate buffer containing $0.05 \%$ ruthenium red, they were fixed in $1 \%$ (wt/vol) $\mathrm{OsO}_{4}$ in $0.07 \mathrm{M}$ cacodylate buffer. The samples were embedded in Epon, and ultrathin sections were stained with $2 \%$ uranyl acetate in $50 \%$ ethanol and then with lead citrate. Micrographs were taken with a JEOL model $1200 \mathrm{CX}$ electron microscope.

DNA base composition. DNA was isolated and purified by chromatography on hydroxyapatite. The guanine-plus-cytosine $(\mathrm{G}+\mathrm{C})$ content was determined by HPLC, using the method of Meshbah et al. (11). Nonmethylated lambda DNA (Sigma) was used as the standard.

DNA relatedness. DNA was extracted and purified as described elsewhere (3). The exact procedures used for in vitro labelling of DNA with tritium-labelled nucleotides and for hybridization experiments ( $\mathrm{S} 1$ nuclease-trichloroacetic acid procedure) have been described previously (7). The temperature at which $50 \%$ of the reassociated DNA became hydrolyzable by the $\mathrm{S} 1$ nuclease $\left(T_{m}\right)$ was determined as described by Crosa et al. (5). The difference between the $T_{m}$ of a homoduplex and the $T_{m}$ of a heteroduplex $\left(\Delta T_{m}\right)$ provided an estimate of the divergence between two DNAs (2).

\section{RESULTS}

Isolation. Three strains that grew in the presence of 100 , 150 , and $200 \mathrm{~g}$ of $\mathrm{NaCl}$ per liter were isolated. The metabolic properties of the isolate obtained from medium containing 150 $\mathrm{g}$ of $\mathrm{NaCl}$ per liter (strain $\mathrm{H} 150^{\mathrm{T}}$ ) were significantly different from the metabolic properties of the two other isolates. Isolate $\mathrm{H} 150^{\mathrm{T}}$ was characterized further. Single colonies of this organism were yellow, flat, and circular, had smooth edges, and were 0.5 to $1 \mathrm{~mm}$ in diameter (depending on the age).

Cellular properties. Strain $\mathrm{H} 150^{\mathrm{T}}$ cells were straight rods that were 0.4 to 0.6 by 2 to $5 \mu \mathrm{m}$ and occurred singly or in pairs (Fig. 1); these cells were motile by means of peritrichous flagella (Fig. 2). Thin sections revealed a typical gram-negative cell envelope profile and a multilayer cell wall (Fig. 3).

The distribution fatty acid in the membrane phospholipids is shown in Table 1 . No branched fatty acids were found. Monounsaturated fatty acids accounted for $57 \%$ of the total fatty acids, with $\mathrm{C}_{16: 1 \Delta 9 \mathrm{c}}$ predominating. Cyclopropane fatty acid was also present as cyclo- $\mathrm{C}_{17: 0}$.

The hydroxy fatty acid profile revealed that a high level of $3 \mathrm{OH}-\mathrm{C}_{12: 0}$ was present (Table 1). $3 \mathrm{OH}-\mathrm{C}_{10: 0}, 3 \mathrm{OH}-\mathrm{C}_{12: 0}$, and $3 \mathrm{OH}-\mathrm{C}_{14: 0}$ are known constituents of lipopolysaccharides in gram-negative bacteria. $\mathrm{C}_{14: 0}$ was the major saturated fatty acid present in strain $\mathrm{H} 150^{\mathrm{T}}$. No archaebacterial isopranyl glyceroether lipids or other hydrophobic residues were detected. Growth of strain $\mathrm{H} 150^{\mathrm{T}}$ was completely inhibited by penicillin $\mathrm{G}$ at a concentration of $33 \mathrm{U} \mathrm{ml}^{-1}$ and by cephalosporin $\mathrm{C}$, novobiocin, or vancomycin at a concentration of 100 


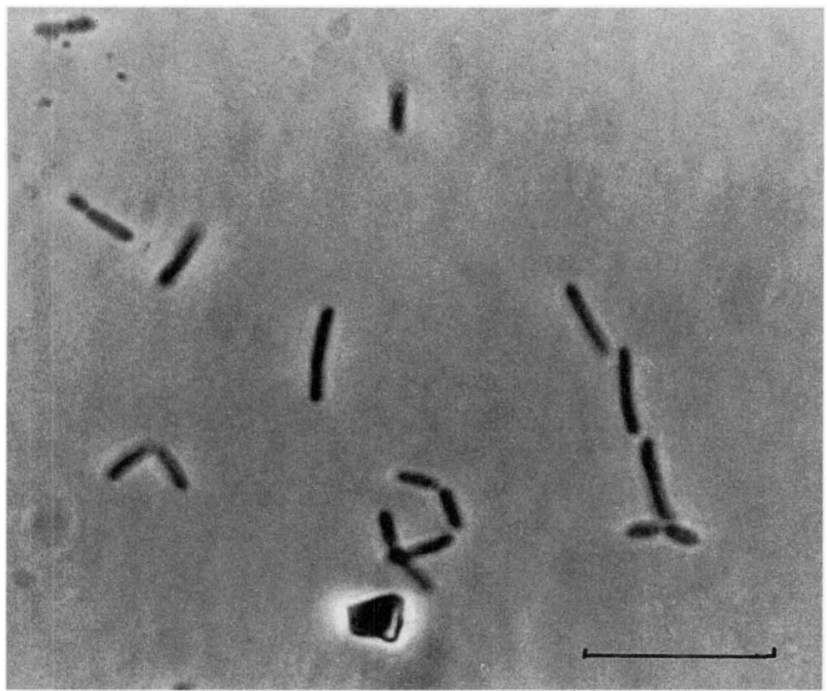

FIG. 1. Phase-contrast photomicrograph of strain $\mathrm{H} 150^{\mathrm{T}}$. Bar $=10$ $\mu \mathrm{m}$.

$\mu \mathrm{g} \mathrm{ml}^{-1}$ and was partially inhibited by chloramphenicol at a concentration of $200 \mu \mathrm{g} \mathrm{ml} \mathrm{m}^{-1}$.

Growth and metabolic properties. The optimum temperature for growth of strain $\mathrm{H} 150^{\mathrm{T}}$ was about $40^{\circ} \mathrm{C}$, and growth occurred at temperatures between 25 and $45^{\circ} \mathrm{C}$. The optimum $\mathrm{pH}$ was 7; no growth was detected below $\mathrm{pH} 6.3$ and above $\mathrm{pH}$
8.7. Strain $\mathrm{H} 150^{\mathrm{T}}$ required $\mathrm{NaCl}$ but not $\mathrm{MgCl}_{2}$. Optimum growth occurred at $\mathrm{NaCl}$ concentrations between 7.5 and $12.5 \%$. A minimum of $5 \% \mathrm{NaCl}$ was required for growth; growth inhibition occurred at $\mathrm{NaCl}$ concentrations above $25 \%$. Magnesium was tolerated up to a concentration of $1 \mathrm{M}$. A minimum doubling time of $4.2 \mathrm{~h}$ was determined for the isolate cultivated on glucose-containing medium in the presence of 1 $\mathrm{g}$ of bio-Trypticase per liter, $1 \mathrm{~g}$ of yeast extract per liter, and $150 \mathrm{~g}$ of $\mathrm{NaCl}$ per liter. Strain $\mathrm{H} 150^{\mathrm{T}}$ was found to be an obligate anaerobe. Spores were not observed, and no growth was obtained after pasteurization at $90^{\circ} \mathrm{C}$ for $20 \mathrm{~min}$.

The following compounds could be used as energy sources: cellobiose, fructose, glucose, maltose, lactose, glycerol, mannitol, mannose, ribose, raffinose, and sucrose. No growth was observed with the following compounds: acetate, butyrate, ethanol, formate, ethylene glycol, methanol, trimethylamine, propionate, adonitol, fumarate, galactose, gluconate, malate, arabinose, pectin, lactate, cellulose, Casamino Acids, rhamnose, xylose, and sorbose. The products of glucose fermentation were acetate (approximately $2 \mathrm{~mol} / \mathrm{mol}$ of glucose degraded), $\mathrm{H}_{2}$, and $\mathrm{CO}_{2} \cdot \mathrm{H}_{2}$ was not used as an electron donor to reduce $\mathrm{CO}_{2}$ to acetate. No ethanol was detected.

DNA base composition. The average DNA base composition of strain $\mathrm{H} 150^{\mathrm{T}}$, based on the results of three HPLC determinations, was $31.7 \pm 0.3 \mathrm{~mol} \% \mathrm{G}+\mathrm{C}$.

DNA relatedness. The levels of DNA relatedness between strain $\mathrm{H} 150^{\mathrm{T}}$ and five other type strains are shown in Table 2. Haloincola saccharolytica $\mathrm{Z}-7787^{\mathrm{T}}$ was $71 \%$ related to strain $\mathrm{H} 150^{\mathrm{T}}\left(\Delta T_{m}\right.$ value, $\left.6.0^{\circ} \mathrm{C}\right)$.

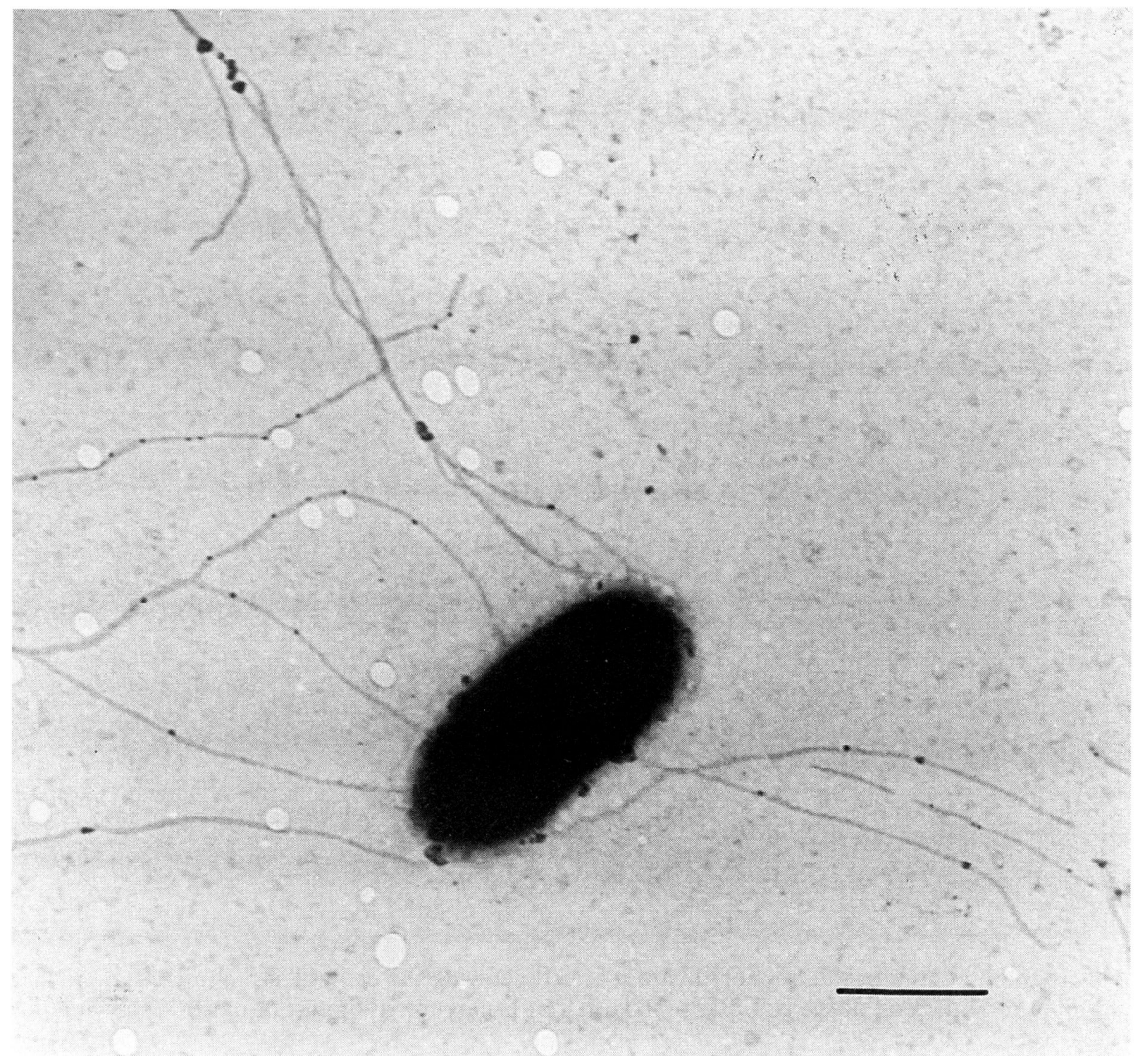

FIG. 2. Electron micrograph of negatively stained strain $\mathrm{H} 150^{\mathrm{T}}$ showing peritrichous flagellation. Bar $=1 \mu \mathrm{m}$. 

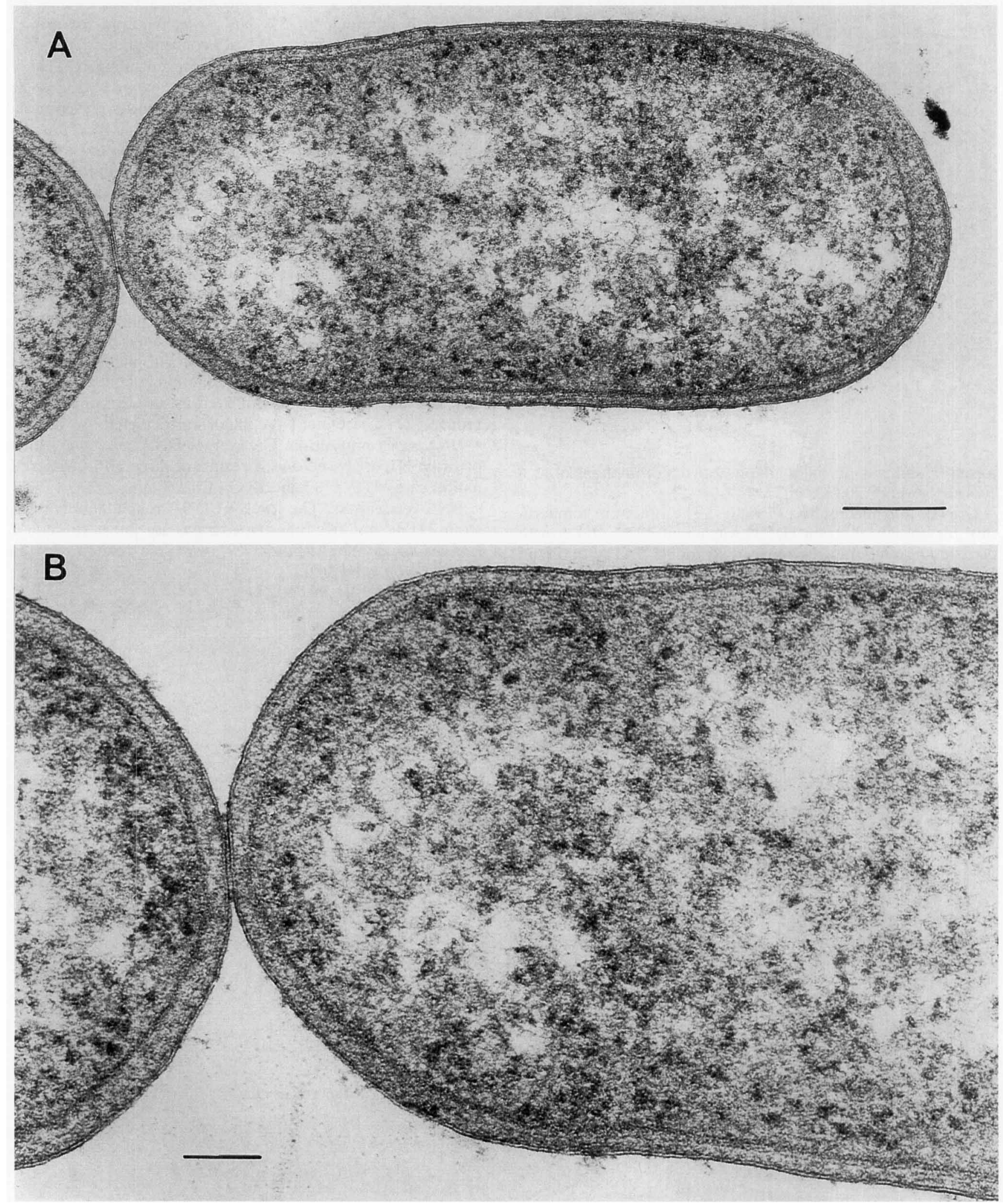

FIG. 3. (A) Electron micrograph of an ultrathin section of strain $H 150^{\mathrm{T}}$ showing the cell wall structure. Note the large interwall space (width, $40 \mathrm{~nm}$ ), which was larger $(100 \mathrm{~nm})$ at the end of the cell. Bar $=0.2 \mu \mathrm{m}$. (B) Enlargement of part of panel A showing the thin peptidoglycan layer in mean position. Bar $=0.1 \mu \mathrm{m}$. 
TABLE 1. Fatty acids and hydroxy fatty acids in membrane phospholipids of strain $\mathrm{H} 150^{\mathrm{T}}$ and Haloincola saccharolytica $\mathrm{Z}-7787^{\mathrm{T}}$

\begin{tabular}{|c|c|c|}
\hline \multirow{2}{*}{$\begin{array}{l}\text { Fatty acid } \\
\text { methyl ester }\end{array}$} & \multicolumn{2}{|c|}{$\%$ of total fatty acids in: } \\
\hline & Strain $\mathrm{H} 150^{\mathrm{T}}$ & Strain Z-7787 ${ }^{\mathrm{T} u}$ \\
\hline \multicolumn{3}{|l|}{ Fatty acids } \\
\hline$C_{12 \cdot 0}$ & 0.4 & $\mathrm{ND}^{b}$ \\
\hline $\mathrm{C}_{13: 0}$ & 0.9 & ND \\
\hline$C_{14: 1 \Delta S c}$ & 0.2 & ND \\
\hline$C_{14: 1 \Delta 7 c}$ & 2.6 & ND \\
\hline$C_{14: 1 \Delta 9 \mathrm{c}}$ & 1.9 & 2.4 \\
\hline $\mathrm{C}_{14: 1 \Delta 11}$ & ND & 1.8 \\
\hline $\mathrm{C}_{14: 0}$ & 20.9 & 6.7 \\
\hline $\mathrm{C}_{15: 1 \Delta 7 \mathrm{c}}$ & 3.3 & ND \\
\hline $\mathrm{C}_{15: 1 \Delta 9 \mathrm{c}}$ & 8.9 & 3.3 \\
\hline $\mathrm{C}_{15: 1 \Delta 11}$ & ND & 10.3 \\
\hline $\mathrm{C}_{15: 0}$ & 7.2 & 3.3 \\
\hline $\mathrm{C}_{16: 1 \Delta 5 \mathrm{c}}$ & 7.3 & ND \\
\hline $\mathrm{C}_{16: 1 \Delta 9_{\mathrm{c}}}$ & 23.4 & 32.9 \\
\hline $\mathrm{C}_{16: 1 \Delta 11 \mathrm{c}}$ & 7.7 & 12.1 \\
\hline $\mathrm{C}_{16: 0}$ & 11.1 & 15.3 \\
\hline $\mathrm{C}_{17: 1 \Delta 9 \mathrm{c}}$ & 1.2 & 2.0 \\
\hline $\mathrm{C}_{17: 1 \Delta 11}$ & ND & 6.0 \\
\hline Cyclo $C_{17: 0}$ & 2.2 & ND \\
\hline $\mathrm{C}_{17: 0}$ & 0.2 & 0.7 \\
\hline $\mathrm{C}_{18: 1}$ & ND & 2.0 \\
\hline $\mathrm{C}_{18: 1 \Delta 9_{\mathrm{c}}}$ & 0.3 & ND \\
\hline $\mathrm{C}_{18: 1 \Delta 11 \mathrm{c}}$ & 0.2 & ND \\
\hline $\mathrm{C}_{18: 1 \Delta 13 \mathrm{c}}$ & 0.1 & ND \\
\hline $\mathrm{C}_{18: 0}$ & 0.1 & 1.2 \\
\hline \multicolumn{3}{|l|}{ Hydroxy fatty acids } \\
\hline $3 \mathrm{OH}-\mathrm{C}_{10: 0}$ & 7.2 & 12.1 \\
\hline br $3 \mathrm{OH}-\mathrm{C}_{11: 0}{ }^{c}$ & 2.5 & ND \\
\hline $3 \mathrm{OH}-\mathrm{C}_{11: 1}$ & ND & 8.0 \\
\hline $3 \mathrm{OH}-\mathrm{C}_{11: 0}$ & 10.4 & 12.3 \\
\hline $3 \mathrm{OH}-\mathrm{C}_{12: 1}{ }^{d}$ & 17.4 & 48.0 \\
\hline $3 \mathrm{OH}-\mathrm{C}_{12: 0}$ & 50.0 & 16.2 \\
\hline br $3 \mathrm{OH}-\mathrm{C}_{13: 0}$ & 2.4 & ND \\
\hline $3 \mathrm{OH}-\mathrm{C}_{13: 1}$ & ND & 2.1 \\
\hline $3 \mathrm{OH}-\mathrm{C}_{13 \cdot 0}$ & 2.8 & 1.3 \\
\hline $3 \mathrm{OH}-\mathrm{C}_{14: 0}$ & 4.6 & ND \\
\hline $3 \mathrm{OH}-\mathrm{C}_{16: 0}$ & 2.7 & ND \\
\hline
\end{tabular}

${ }^{a}$ Data from reference 27 .

${ }^{b} \mathrm{ND}$, not detected.

c br, branched.

${ }^{d}$ Double bond position not identified.

\section{DISCUSSION}

The characteristics of isolate $\mathrm{H} 150^{\mathrm{T}}$ indicated that it was a new, strictly halophilic, anaerobic, rod-shaped organism that used carbohydrates as energy sources. Strain $\mathrm{H} 150^{\mathrm{T}}$ was a moderate halophile which grew in the presence of $\mathrm{NaCl}$ concentrations between 0.8 and $4.3 \mathrm{M}$. Its morphology, physiology, and genetic properties were consistent with assignment to the family Haloanaerobiaceae. The only fatty acid produced from glucose fermentation was acetate. Therefore, we concluded that strain $\mathrm{H} 150^{\mathrm{T}}$ was affiliated with the two anaerobic, halophilic, homoacetogenic, fermentative species that have been described previously, $A$. arabaticum and Haloincola saccharolytica. However, Haloincola saccharolytica and strain $\mathrm{H} 150^{\mathrm{T}}$ can be easily distinguished from $A$. arabaticum by the ability to utilize sugars; $A$. arabaticum does not utilize sugars, but Haloincola saccharolytica does. Furthermore, as determined by DNA-DNA hybridization, Haloincola saccharolytica and strain $\mathrm{H}_{150^{\mathbf{T}}}$ are more closely related to each other than to the other members of the family Haloanaerobiaceae, including the genera Halobacteroides, Haloanaerobium, and Sporoha-
TABLE 2. Levels of DNA relatedness between isolate $\mathrm{H} 150^{\mathrm{T}}$ and related bacteria

\begin{tabular}{|c|c|}
\hline Source of unlabelled DNA & $\begin{array}{c}\% \text { Relatedness } \\
\text { to }{ }^{3} \mathrm{H} \text {-labelled } \\
\text { DNA from } \\
\text { strain } \mathrm{H} 150^{\mathrm{T}}\end{array}$ \\
\hline Strain $\mathrm{H} 150^{\mathbf{T}}$. & $100(0.0)^{a}$ \\
\hline Haloincola saccharolytica $\mathrm{Z}-7787^{\mathrm{C}}$.. & $71(6.0)$ \\
\hline Sporohalobacter marismortui $\mathrm{DY}-1^{\mathrm{T}}$... & 1 \\
\hline Sporohalobacter lortetii $\mathrm{MD}-2^{\mathrm{T}} \ldots \ldots \ldots \ldots$ & 1 \\
\hline Halobacteroides acetoethylicus $\mathrm{EIGI}^{\mathrm{T}}$. & 11 \\
\hline Haloanaerobium praevalens $\mathrm{GSL}^{\mathrm{T}}$ & 9 \\
\hline
\end{tabular}

${ }^{a}$ The values in parentheses are $\Delta T_{m}$ values (in degrees Celsius).

lobacter (Table 2). Strain $\mathrm{H} 150^{\mathrm{T}}$ differs from Haloincola saccharolytica in oxidizing raffinose (Table 3); furthermore, no growth occurs on media containing L-xylose, galactose, and gluconate. In contrast to strain $\mathrm{H} 150^{\mathrm{T}}$, Haloincola saccharolytica grows in the presence of $30 \% \mathrm{NaCl}$ and has a faster doubling time $(3 \mathrm{~h}$, instead of the 4.2 -h doubling time of strain $\mathrm{H} 150^{\mathrm{T}}$ ). Strain $\mathrm{H} 150^{\mathrm{T}}$ and Haloincola saccharolytica both contain straight-chain $\mathrm{C}_{16}$ fatty acids as the main membrane components. However, strain $\mathrm{H}_{150^{\mathrm{T}}}$ differs from Haloincola saccharolytica in the distribution of other fatty acids. Indeed, saturated $\mathrm{C}_{12: 0}$ and $\mathrm{C}_{13: 0}$ have not been found in Haloincola saccharolytica. Furthermore, strain $\mathrm{H}_{150^{\mathrm{T}}}$ is characterized by a higher level of $\mathrm{C}_{14: 0}$ than Haloincola saccharolytica. Differences also occur in the positions of the double bonds in $\mathrm{C}_{14}$, $\mathrm{C}_{15}$, and $\mathrm{C}_{16}$ fatty acids. The unsaturated hydroxy fatty acid $3 \mathrm{OH}-\mathrm{C}_{12: 1}$ is not common, and additional investigations will be needed to determine its biosynthetic pathway.

As observed by Zhilina et al. (27), in hypersaline ecosystems Haloincola saccharolytica and probably strain $\mathrm{H} 150^{\mathrm{T}}$ might be involved in anaerobic oxidation of compatible solutes, such as glycerol, which is usually produced by Dunaliella salina (6). The fate of this organic compound in hypersaline environments is of interest, particularly with regard to electron transfer from glycerol to biological acceptors such as sulfate reducers. Oxidation of sucrose and trehalose by these organisms indicated that they might also be responsible for degrading other organic osmolytes since such sugars are found in the cytoplasm of halotolerant cyanobacteria (18) that are abundant on the shore of Retba Lake (the source of strain $\mathrm{H} 150^{\mathrm{T}}$ ) during the dry season (20). After being washed out from the shore by rain during the wet season, algae provide suitable substrates for these halophilic eubacteria.

The results of DNA-DNA hybridization experiments indicated that there is a close relationship between strain $\mathrm{H} 150^{\mathrm{T}}$ and Haloincola saccharolytica. However, the values which we obtained are at the borderline of the range used to distinguish species (22). Since physiological and metabolic properties of strain $\mathrm{H}_{150^{\mathrm{T}}}$ are different from Haloincola saccharolytica properties, we propose that strain $\mathrm{H} 150^{\mathrm{T}}$ is a member of a subspecies of Haloincola saccharolytica, Haloincola saccharolytica subsp. senegalensis. This proposal automatically creates Haloincola saccharolytica subsp. saccharolytica.

Emendation of the species description of Haloincola saccharolytica Zhilina, Zavarzin, Bulygina, Kevbrin, Osipov, and Chumakov 1992. Haloincola saccharolytica (sac.cha.ro.ly'ti.ca. Gr. n. sacchar, sugar; Gr. adj. lyticus, able to dissolve, decompose; M. L. adj. saccharolytica, digesting sugar). Short rods that are 0.4 to 0.7 by 1 to $5 \mu \mathrm{m}$. Cells occur singly or in pairs and are motile by means of peritrichous flagella. Colonies are raised, circular, 0.5 to $2 \mathrm{~mm}$ in diameter, and white with glossy 
TABLE 3. Characteristics that distinguish strain $\mathrm{H} 150^{\mathrm{T}}$ from Haloincola saccharolytica $\mathrm{Z}-7787^{\mathrm{T}}$

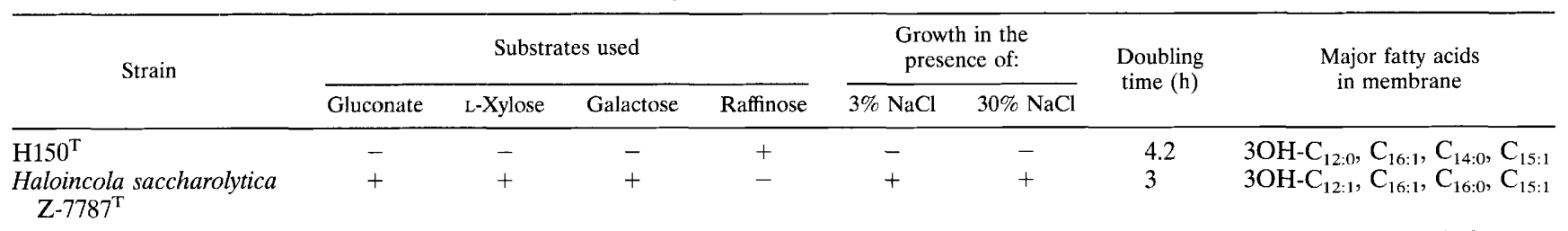

${ }^{a}$ Substrate utilization and growth comparison tests were performed in the same culture media (see Materials and Methods).

surfaces. Obligately halophilic. The optimum $\mathrm{NaCl}$ concentration for growth is 7.5 to $12.5 \%$; the $\mathrm{NaCl}$ concentration range for growth is 3 to $30 \%$. Mesophilic. The optimum growth temperature is 37 to $40^{\circ} \mathrm{C}$; the temperature range for growth is 15 to $47^{\circ} \mathrm{C}$. The $\mathrm{pH}$ range for growth is $\mathrm{pH} 6.0$ to 8.5 ; the optimum $\mathrm{pH}$ is $\mathrm{pH} 7.0$ to 7.5 . Obligate anaerobe. Chemoorganotrophic. Ferments carbohydrates. The end products of sugar fermentation are acetate, $\mathrm{H}_{2}$, and $\mathrm{CO}_{2}$. The $\mathrm{G}+\mathrm{C}$ content of the DNA is 31 to $32 \mathrm{~mol} \%$. Isolated from hypersaline lakes.

Description of Haloincola saccharolytica subsp. saccharolytica Zhilina, Zavarzin, Bulygina, Kevbrin, Osipov, and Chumakov 1992. Haloincola saccharolytica subsp. saccharolytica (sac.cha. ro.ly'ti.ca. Gr. n. sacchar, sugar; Gr. adj. lyticus, able to dissolve, decompose; M. L. adj. saccharolytica, digesting sugar). Short rods that are 0.5 to 0.7 by 1 to $1.5 \mu \mathrm{m}$. Cells occur singly or in pairs and are motile by means of a few peritrichous flagella. Colonies are raised, circular, 1 to $2 \mathrm{~mm}$ in diameter, and white with glossy surfaces. Obligately halophilic. The optimum $\mathrm{NaCl}$ concentration for growth is $10 \%$; the $\mathrm{NaCl}$ concentration range for growth is 3 to $30 \%$. Mesophilic. The optimum growth temperature is 37 to $40^{\circ} \mathrm{C}$; the temperature range for growth is 15 to $47^{\circ} \mathrm{C}$. The $\mathrm{pH}$ range for growth is $\mathrm{pH}$ 6.0 to 8.0 ; the optimum $\mathrm{pH}$ is $\mathrm{pH} 7.5$. Obligate anaerobe. Chemoorganotrophic. Ferments carbohydrates, including sucrose, cellobiose, trehalose, maltose, lactose, melibiose, glucose, fructose, and ribose. The end products of fermentation are acetate, $\mathrm{H}_{2}$, and $\mathrm{CO}_{2}$. The $\mathrm{G}+\mathrm{C}$ content of the DNA is $31.3 \mathrm{~mol} \%$ (as determined by thermal denaturation). Isolated from a hypersaline lagoon of Lake Sivash with a cyanobacterial mat. The type strain is Z-7787 (= DSM 6645).

Description of Haloincola saccharolytica subsp. senegalensis subsp. nov. Haloincola saccharolytica subsp. senegalensis (se. ne. ga. len'sis. N. L. adj. senegalensis, from Senegal, West Africa). Cells are straight rods that are 0.4 to 0.6 by 2 to $5 \mu \mathrm{m}$ and are motile by means of peritrichous flagella. Halophilic obligate anaerobe. Grows fastest at $\mathrm{NaCl}$ concentrations between 7.5 and $12.5 \%$ and is inhibited by $\mathrm{NaCl}$ concentrations over $25 \%$ and below $5 \%$. Produces acetate, $\mathrm{H}_{2}$, and $\mathrm{CO}_{2}$ from carbohydrate metabolism. The optimum growth temperature is $40^{\circ} \mathrm{C}$; the temperature range for growth is 20 to $47^{\circ} \mathrm{C}$. The $\mathrm{pH}$ range for growth is $\mathrm{pH} 6.3$ to 8.7 ; the optimum $\mathrm{pH}$ is 7.0. Differs from Haloincola saccharolytica subsp. saccharolytica mainly by using raffinose but not L-xylose, galactose, and gluconate, by growing in the presence of a different range of $\mathrm{NaCl}$ concentrations, and by the fatty acid distribution in its membrane phospholipids. The level of DNA-DNA hybridization with Haloincola saccharolytica subsp. saccharolytica is $71 \%$. The $\mathrm{G}+\mathrm{C}$ content of the DNA is $31.7 \pm 0.3 \mathrm{~mol} \%$ (as determined by HPLC). Type strain $\mathrm{H} 150$ has been deposited in the Deutsche Sammlung von Mikroorganismen und Zellkulturen as strain DSM 7379; it was isolated from sediments of Retba Lake, a hypersaline lake in Senegal.

\section{ACKNOWLEDGMENTS}

We are indebted to K. D. Jahnke, Deutsche Sammlung von Mikroorganismen und Zellkulturen, for determining the DNA base ratio and C. Allasia for technical assistance. We thank P. Roger for revising the manuscript and B. K. C. Patel for helpful discussions.

\section{REFERENCES}

1. Balch, W. E., G. E. Fox, L. J. Magrum, C. R. Woese, and R. S. Wolfe. 1979. Methanogens: reevaluation of a unique biological group. Microbiol. Rev. 43:260-296.

2. Brenner, D. J. 1978. Characterization and clinical identification of Enterobacteriaceae by DNA hybridization. Prog. Clin. Pathol. 7:71-117.

3. Brenner, D. J., A. C. McWhorter, J. K. Leete-Knudson, and A. G. Steigerwalt. 1982. Escherichia vulneris: a new species of Enterobacteriaceae associated with human wounds. J. Clin. Microbiol. 15: $1133-1140$.

4. Cayol, J.-L., B. Ollivier, B. K. C. Patel, G. Prensier, J. Guezennec, and J.-L. Garcia. 1994. Isolation and characterization of Halothermothrix orenii gen. nov., sp. nov., a halophilic, thermophilic, fermentative, strictly anaerobic bacterium. Int. J. Syst. Bacteriol. 44:534-540.

5. Crosa, J. H., D. J. Brenner, and S. Falkow. 1973. Use of a single-strand-specific nuclease for analysis of bacterial and plasmid deoxyribonucleic acid homo- and heteroduplexes. J. Bacteriol. 115:904-911.

6. Gilmour, D. 1990. Halotolerant and halophilic microorganisms, p. 147-178. In C. Edwards (ed.), Microbiology of extreme environments. McGraw-Hill Publishing Co., Oxford.

7. Grimont, P. A. D., M. Y. Popoff, F. Grimont, C. Coynault, and M. Lemelin. 1980. Reproducibility and correlation study of three deoxyribonucleic acid hybridization procedures. Curr. Microbiol. 4:325-330.

8. Hungate, R. E. 1969. A roll-tube method for the cultivation of strict anaerobes. Methods Microbiol. 3B:117-132.

9. Imhoff-Stuckle, D., and N. Pfennig. 1983. Isolation and characterization of a nicotinic acid-degrading sulfate-reducing bacterium, Desulfococcus niacini sp. nov. Arch. Microbiol. 136:194-198.

10. Liaw, H., and R. A. Mah. 1992. Isolation and characterization of Haloanaerobacter chitinovorans gen. nov., sp. nov., a halophilic, anaerobic, chitinolytic bacterium from a solar saltern. Appl. Environ. Microbiol. 58:260-266.

11. Meshbah, M., U. Premachandran, and W. Whitman. 1989. Precise measurement of the $\mathrm{G}+\mathrm{C}$ content of deoxyribonucleic acid by high-performance liquid chromatography. Int. J. Syst. Bacteriol. 39:159-167.

12. Ollivier, B., P. Caumette, J.-L. Garcia, and R. A. Mah. 1994. Anaerobic bacteria from hypersaline environments. Microbiol. Rev. 58:27-38.

13. Ollivier, B., C. Hatchikian, G. Prensier, J. Guezennec, and J.-L. Garcia. 1991. Desulfohalobium retbaense gen. nov., sp. nov., a halophilic sulfate-reducing bacterium from sediments of a hypersaline lake in Senegal. Int. J. Syst. Bacteriol. 41:74-81.

14. Oren, A. 1988. Anaerobic degradation of organic compounds at high salt concentrations. Antonie van Leeuwenhoek 54:267-277.

15. Oren, A., B. J. Paster, and C. R. Woese. 1984. Haloanaerobiaceae: a new family of moderately halophilic obligatory anaerobic bacteria. Syst. Appl. Microbiol. 5:71-80. 
16. Oren, A., H. Pohla, and E. Stackebrandt. 1987. Transfer of Clostridium lortetii to a new genus Sporohalobacter gen. nov. as Sporohalobacter lortetii comb. nov., and description of Sporohalobacter marismortui sp. nov. Syst. Appl. Microbiol. 9:239-246.

17. Oren, A., W. G. Weisburg, M. Kessel, and C. R. Woese. 1984 Halobacteroides halobius gen. nov., sp. nov., a moderately halophilic anaerobic bacterium from the bottom sediments of the Dead Sea. Syst. Appl. Microbiol. 5:58-70.

18. Reed, R. H., L. J. Borowitzka, M. A. Mackay, J. A. Chudek, R. Foster, S. R. C. Warr, D. J. Moore, and W. D. P. Stewart. 1986. Organic solute accumulation in osmotically stressed cyanobacteria. FEMS Microbiol. Rev. 39:51-56.

19. Rengpipat, S., S. E. Lowe, and J. G. Zeikus. 1988. Effect of extreme salt concentrations on the physiology and biochemistry of Halobacteroides acetoethylicus. J. Bacteriol. 170:3065-3071.

20. Reynaud, P. A., and P. A. Roger. 1981. Variations saisonnières de la flore algale et de l'activité fixatrice d'azote dans un sol engorgé de dune. Rev. Ecol. Biol. Sol 18:9-27.

21. Simankova, M. V., N. A. Chernych, G. A. Osipov, and G. A. Zavarzin. 1993. Halocella cellulolytica gen. nov., sp. nov., a new obligately anaerobic, halophilic, cellulolytic bacterium. Syst. Appl. Microbiol. 16:385-389.

22. Wayne, L. G., D. J. Brenner, R. R. Colwell, P. A. D. Grimont, 0. Kandler, M. I. Krichevsky, L. H. Moore, W. E. C. Moore, R. G. E. Murray, E. Stackebrandt, M. P. Starr, and H. G. Trüper. 1987.
Report of the Ad Hoc Committee on Reconciliation of Approaches to Bacterial Systematics. Int. J. Syst. Bacteriol. 37:463464.

23. White, D. C., W. M. Davis, J. S. Nickels, J. D. King, and R. J. Bobbie. 1979. Determination of the sedimentary microbial biomass by extractable lipid phosphate. Oecologia (Berlin) 40:51-62.

24. Zeikus, J. G., P. W. Hegge, T. E. Thompson, T. J. Phelps, and T. A. Langworthy. 1983. Isolation and description of Haloanaerobium praevalens gen. nov. and sp. nov., an obligately anaerobic halophile common to Great Salt Lake sediments. Curr. Microbiol. 9:225234.

25. Zhilina, T. N., L. V. Miroshnikova, G. A. Osipov, and G. A. Zavarzin. 1992. Halobacteroides lacunaris sp. nov., a new saccharolytic, anaerobic, extremely halophilic organism from the lagoonlike hypersaline Lake Chokrak. Mikrobiologiya (Engl. Tr.) 60: 495-503.

26. Zhilina, T. N., and G. A. Zavarzin. 1990. A new extremely halophilic homoacetogen bacterium Acetohalobium arabaticum gen. nov., sp. nov. Dokl. Akad. Nauk SSSR 311:745-747.

27. Zhilina, T. N., G. A. Zavarzin, E. S. Bulygina, V. V. Kevbrin, G. A. Osipov, and K. M. Chumakov. 1992. Ecology, physiology and taxonomy studies on a new taxon of Haloanaerobiaceae, Haloincola saccharolytica gen. nov., sp. nov. Syst. Appl. Microbiol. 15: 275-284. 